\title{
Testing of the ammunition stabilization-deceleration system structure in static conditions and in the subsonic aerodynamic tunnel
}

\section{REZUMAT - ABSTRACT}

Testarea structurii sistemului de stabilizare-decelerare a armamentului în condiții statice și în tunelul aerodinamic subsonic

Utilizarea sistemului de stabilizare-decelerare aerodinamică asigură numeroase avantaje în ghidarea și detonarea armamentului în teatrul operațiunilor, respective elargarea cu precizie a armamentului în situația în care mecanismele de autodistrugere sau dezactivare nu funcționează, iar traiectoria indică bombardarea unor zone populate de civili sau a unor obiective civile (construcții industriale, uzine de producție, poduri, viaducte). În acest context, lucrarea prezintă valorile caracteristicilor statice ale voalurii, precum și cele aerodinamice ale unui sistem de stabilizare-decelerare rezultate în urma testărilor în tunelul aerodinamic.

Cuvinte-cheie: sistem de stabilizare-decelerare, ghidare, tunel aerodinamic subsonic, circuit aerodinamic de tip Prandtl, suprafață rezistentă, caracteristici aerodinamice, porozitate sistem, erori standard, regresie multivariată, coeficient de corelație pătratic, predicție, permeabilitate voalură.

\section{Testing of the structure of the ammunition stabilization-deceleration system in static conditions and in the subsonic aerodynamic tunnel}

The use of the aerodynamic stabilization-deceleration system provides numerous advantages in guiding and detonating the ammunition in the theater of operations, namely the precise launching of the ammunition if the self-destruction or deactivation mechanisms do not work and the trajectory indicates the bombing of populated areas or civil targets (industrial constructions, production plants, bridges, viaducts). In this context, the paper presents the values of the static characteristics of the canopy as well as the aerodynamic ones of a stabilization-deceleration system, resulted from the tests performed in the aerodynamic tunnel.

Keywords: stabilization-deceleration system, guidance, subsonic aerodynamic tunnel, Prandtl aerodynamic circuit, resistant surface, aerodynamic characteristics, porosity of the system, standard errors, multivariate regression, square correlation coefficient, prediction, canopy permeability

\section{INTRODUCTION}

The stabilization-deceleration of ammunition (gravity bombs, general-purpose explosive bombs, modular bombs, exercise bombs, flash bombs with time or electronic warhead, unguided reactive missiles) is a very important application for currently worldwide aeronautical research.

The holistic approach of the problem allowed the prediction of the technological stages for the functional models developmentof the woven structures with controllable permeability meant for the canopy of the stabilization-deceleration system. The experiments were carried out on the existing equipments at the The National Research \& Development Institute for Textiles and Leather (INCDTP) (figure 1).

The manufactured variant (V1) was tested in the INCDTP laboratories, accredited according to SR EN ISO/CEI 17025:2001, to investigatethe main physicmechanical characteristics. The obtained results for mass, breaking force, elongation at break, tearing strength, air permeability that are defining for the aerodynamic performance prediction of the vertical- stabilization-deceleration system (oscillation, rotation, drag resistance coefficient) are shown in table 1.

\begin{tabular}{|l|c|c|}
\hline \multicolumn{2}{|c|}{ Characteristics } & Table 1 \\
\hline Mass, g/m ${ }^{2}$ & 80.5 \\
\hline \multirow{2}{*}{ Breaking force, N } & warp & 685 \\
\hline \multirow{2}{*}{ Elongation at break, \% } & weft & 666 \\
\hline \multirow{2}{*}{ Tearing strength, N } & warp & 41.2 \\
& weft & 31.0 \\
\hline Air permeability (surface $20 \mathrm{~cm}^{2}$, water & 24.9 \\
column $10 \mathrm{~mm}, 100 \mathrm{~Pa} / 200 \mathrm{~Pa}$ ) $1 / \mathrm{m}^{2} / \mathrm{s}$ & 32.7 \\
\hline
\end{tabular}

The testing of the outliers was performed using the Dixon test $\left(A_{5: 0,99}=0,821\right.$ and $\left.A_{10: 0,99}=0,568\right)$, demonstrated that the null hypothesis is not denied $\left(\mathrm{H}_{0}\right.$ : the value $X_{(1)}$ is not outlier), and no value of the characteristics is considered an outlier, thus not being excluded from the series of determinations series. 


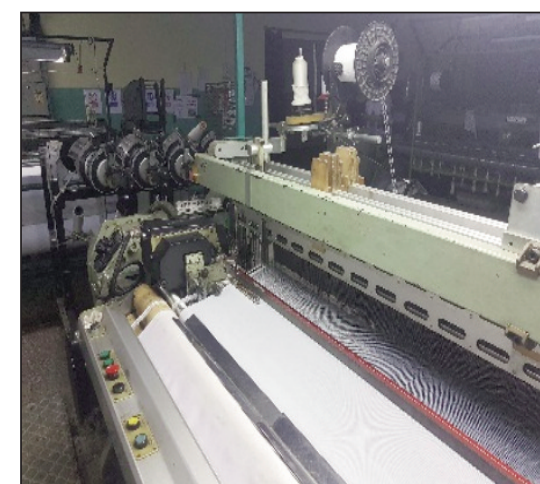

a

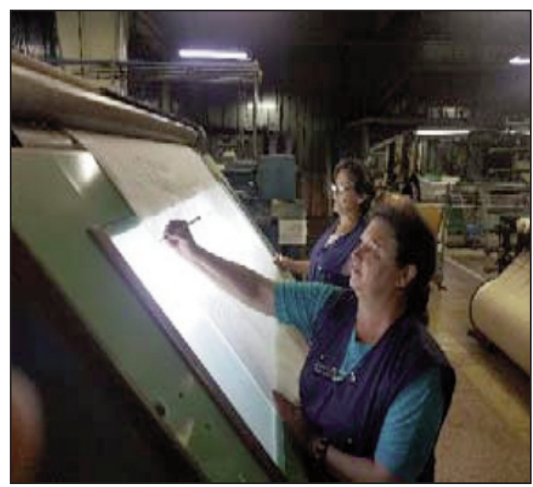

b

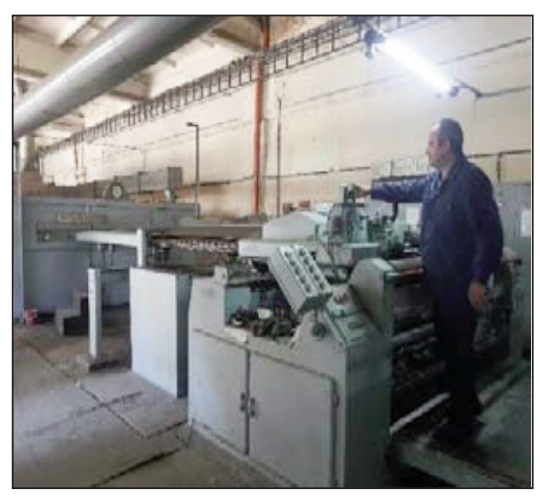

c

Fig. 1. Aspects from the weaving operations (a), quality control (b) and finishing (c) of functional models development of the woven structures with controllable permeability meant for the canopy of the stabilization-deceleration system

The data obtained allow to highlighting the following aspects:

- the maximum breaking force, both in warp and weft directions, allows to absorb the shock load that develops in the canopy of the main parachute during the descent because, regardless of the mass, the launching speed, the ammunition launching altitude, the maximum breaking force of the woven structure in shock conditions is max. $240 \mathrm{~N}$;

- the air permeability fall within the limits imposed for hemi flow or annular parachutes types (1200-1600 $\mathrm{l} / \mathrm{sqm} / \mathrm{s}(100 \mathrm{~Pa})$ ), the obtained value allows the use for ammunition heavier than $200 \mathrm{~kg}$, with a launching speed in theater of operations below $200 \mathrm{ft} / \mathrm{s}$ $(60.96 \mathrm{~m} / \mathrm{s})$. When using another shape of stabilization-deceleration system (e.g. cruciform type), the functional models can be used for masses of $50-100 \mathrm{~kg}$ with a launch speed of $75 \mathrm{ft} / \mathrm{s}(22.80$ $\mathrm{m} / \mathrm{s}$ ) or when using airborne ammunition with a mass greater than $200 \mathrm{~kg}$, launched from high altitudes, at speeds of $50-500 \mathrm{ft} / \mathrm{s}(25,74 \mathrm{~m} / \mathrm{s}-257,4$ $\mathrm{m} / \mathrm{s}$ ), which must be stabilized before entering in the water and decelerate from $100 \mathrm{ft} / \mathrm{s}(30.48 \mathrm{~m} / \mathrm{s})$ to $30 \mathrm{ft} / \mathrm{s}(9.14 \mathrm{~m} / \mathrm{s})$;

- the values obtained for the tearing forces are balanced on the 2 systems, corresponding to the imposed value ( $\min .20 \mathrm{~N}$ ), so the entire stabilization-deceleration assembly will take, in a balanced manner, in all directions, the impact determined by the opening of the parachute at the moment of launch.

\section{Experimentation in the aerodynamic tunnel}

To simulate the real conditions of use, as a stabilization-deceleration system, the MF01 coded version of woven structure (physic-mechanical characteristics according to table 1) was tested in the aerodynamic tunnel in the form of the hemi flow parachute with the main characteristics shown in figure 2 .

Testing was performed in the subsonic aerodynamic tunnel, up to max. $35 \mathrm{~m} / \mathrm{s}$, at The National Institute for Aerospace Research "Elie Carafoli".

The aerodynamic wind tunnel is a tool for testing aerial vehicles and their components, but can also be

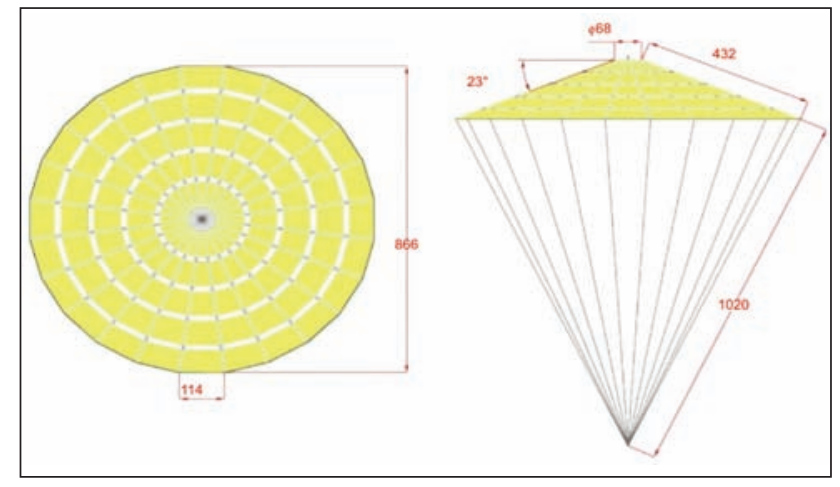

Fig. 2.The shape and dimensions of the parachute MF01 canopy

used successfully to test parachute canopies. Worldwide experiments have shown that the mode of behavior of the parachute model in the aerodynamic wind tunnel is similar to that of the real model, so tunnel testing provides useful information for the values of the drag resistance coefficient and drag resistance for different values of the fluid speed [1-3]. The aerodynamic tunnel consists of an aerodynamic circuit, a drive system and measuring equipment. The aerodynamic circuit (figure 3 ) is Prandtl type, with a single return circuit and closed test section (1). The section of the experimental area has an octagonal shape with the main dimensions of $2.0 \mathrm{~m}$ on the vertical direction and $2.5 \mathrm{~m}$ horizontally. The corners (I, II, III and IV) are provided with a network of deflector blades (5) and an aerodynamic filter (8) is provided in the settling room (6). The motor-compressor assembly (3), also called the drive group, is at the end of the first diffuser (2), near the first bend [1]. The diffuser, opened at an angle of $6^{\circ}$, ensures the transformation of the octagonal section of the experimental area into a circular section. The radial aerodynamic valve (4) has the role of canceling the transversal velocity component, transforming some of the kinetic energy into a pressure jump. The section between corners I and II converts the circular section into a elliptical one, and the third diffuser makes the passage to the octagonal section again. The section between corners III and IV keeps the section constant, but it also 


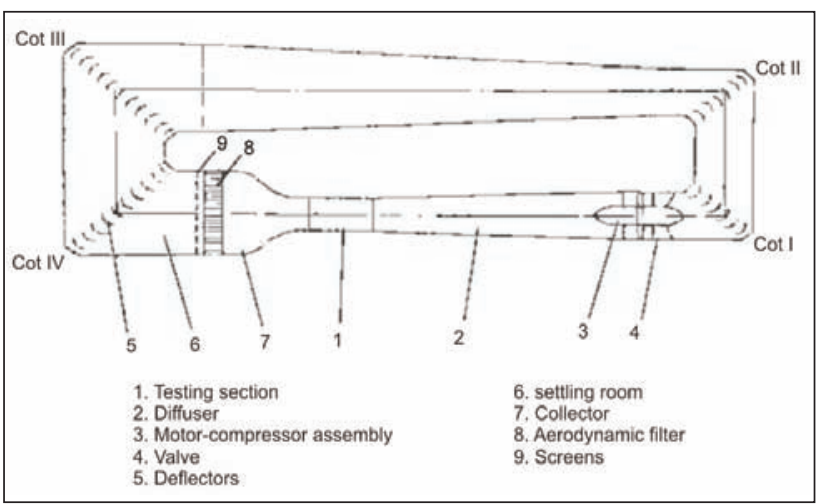

Fig. 3. The aerodynamic circuit of the experimental tunnel [1]
- the total porosity, obtained as the sum of the porosities due to the canopy geometry and the porosity due to the canopy material, greatly influences the performance of a parachute because it affects the system characteristics: drag resistance, stability and shock at opening. Thus, the increase of the total parachute's porosity causes the reducing of the resistance coefficient corresponding for the total surface, for speeds in the range of $10 \mathrm{~m} / \mathrm{s}$ to $30 \mathrm{~m} / \mathrm{s}$, which will cause decrease the shock at the opening for the real parachute of the stabilization-deceleration system [4, 5]. It is advisable to increase the total porosity of the parachute by increasing the porosity due to the fabric

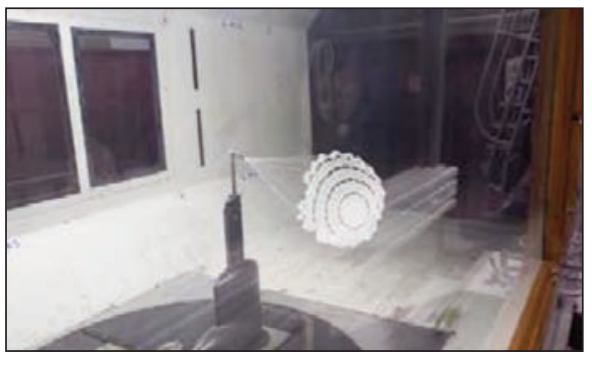

a

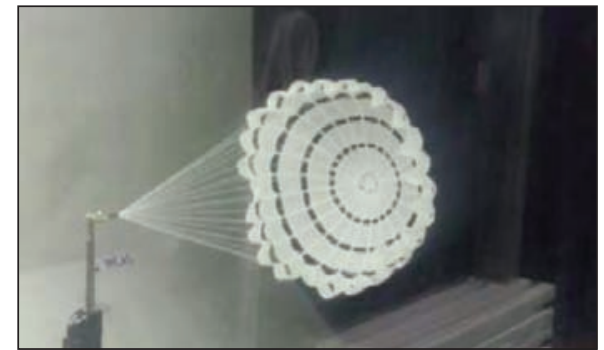

b

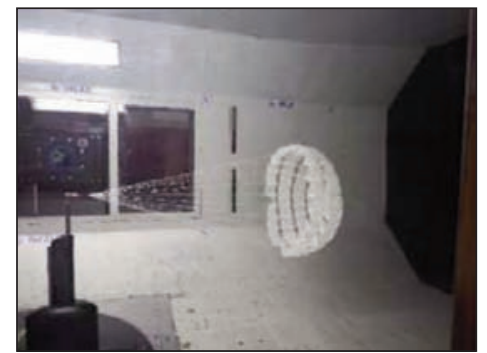

c

Fig. 4.The ME-01 model parachute during the experimentation in the aerodynamic tunnel: $a-10 \mathrm{~m} / \mathrm{s} ; b-20 \mathrm{~m} / \mathrm{s} ; c-30 \mathrm{~m} / \mathrm{s}$

has the role of settling room (6). All the energy introduced into the aerodynamic circuit by the fan dissipates as heat in the concrete construction of the circuit (whose thermal inertia is high). The experimental zone is divergent $\left(1^{\circ}\right)$, thus ensuring the compensation of the boundary layer developed on its solid margins [1]. The system which drives the fluid in the circuit consists of a fan (3), a 2-megawatt DC motor, a command and control system and a command desk. The fluid velocity in the experimental area may vary from $7 \mathrm{~m} / \mathrm{s}$ to $110 \mathrm{~m} / \mathrm{s}$. The measuring equipment used to evaluate the aerodynamic forces and aerodynamic pitching moments developing in the model due to air movement in the experimental area is the 6-components automatic aerodynamic balance. It measures, according to its own reference system, the components of the aerodynamic forces of torsor, in the virtual center. The accuracy of the balance is $1: 25000$. On the rotary frame of the balance is coupled, by a reducer, the motor that provides the change of the rotation angle. The control panel contains all the controls for the weighing instruments.

The behavior of MF01 model in the aerodynamic tunnel during experiments is illustrated in figure 4 and the variation of the drag resistance coefficient $c_{x}$, according to the test speed, is shown in figure 5 .

The measurements made in the subsonic wind tunnel showed the following:

- for low speeds, of up to $10 \mathrm{~m} / \mathrm{s}$, the parachute did not fully open, which led to the calculation of the range of $10-30 \mathrm{~m} / \mathrm{s}$ only;

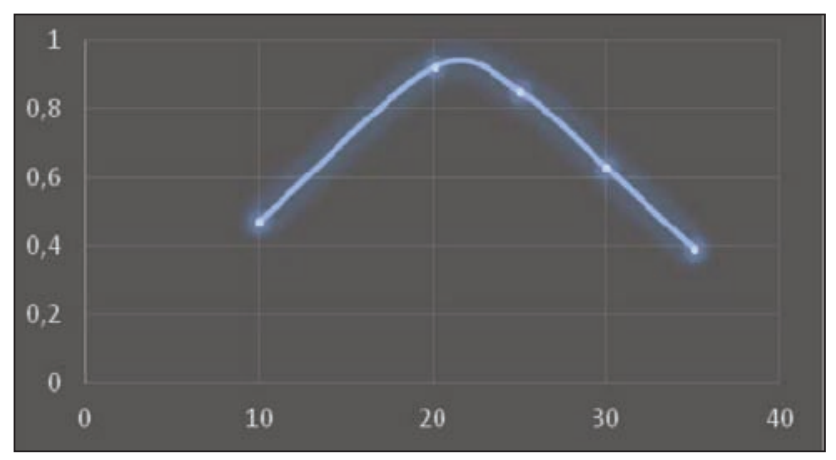

Fig. 5. The variation diagrams for the drag resistance coefficients according to the test speed. The test conditions aerodynamic tunnel:

density: $1.20676363 \mathrm{~kg} / \mathrm{m}^{3}$; temperature: $283.15 \mathrm{~K}$; pressure: $98066.5 \mathrm{~Pa}$; R: $287 \mathrm{~J} / \mathrm{kgK}$

(increasing its permeability), but not above a certain value that could influence the normal attitude of the entire stabilization-deceleration system (figure 6).

The results obtained by testing in the aerodynamic tunnel demonstrate that, in order to obtain small oscillations angles of $\pm 3^{\circ}[1,2]$, recommended for the stabilization-deceleration hemi flow parachute, and therefore a good stability of the system (which implicitly determines its performance: guiding, detonation of the ammunition in the theater of operations, respectively its precise launching) it is necessary that the air permeability of the fabric to be situated in the range of $1400,2500 \mathrm{l} / \mathrm{m}^{2} / \mathrm{s}$. 


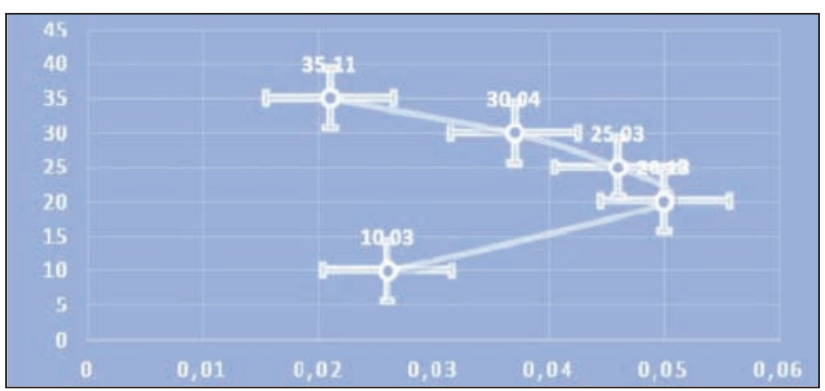

Fig. 6. The graphic representation $c_{x e}=f(v)$ and standard errors

Research on the prediction of air permeability. Multivariate regression

As a premiere in the textile research, in order to predict the air permeability of the structure used for the stabilization-deceleration of the vertical aerodynamic systems, the SPSS specialized software was used. The dependent variable was considered the air permeability, and the independent variables were: the yarns density of the 2 systems and the twists of the yarns from the structures.

The calculations allowed highlighting the following aspects (table 2):

1. The value of the multiple correlation coefficient $R^{2}$ points out that:

- for air permeability, determined at a pressure difference of $100 \mathrm{~Pa}, 94.2 \%$ of the variation of the dependent variable (predicted) is explained by the model, the prediction power being $93.6 \%$;

- for air permeability (pressure difference of $200 \mathrm{~Pa}$ ), $95.6 \%$ of the variation of the dependent variable is explained by the model, the prediction power being $95.1 \%$.

2. The standard error of the predicted dependent variable (air permeability) demonstrates that the standard deviation of air permeability (at $100 \mathrm{~Pa}$ ) is $159.84 \mathrm{l} / \mathrm{mp} / \mathrm{s}$, and for air permeability (200 Pa) is $214.06 \mathrm{l} / \mathrm{mp} / \mathrm{s}$, if the value of independent variables from the model is known.

3. The value of 0.942 (at $100 \mathrm{~Pa}$ ) and 0.956 (at 200 $\mathrm{Pa}$ ), respectively, demonstrates that $\mathrm{R}^{2}$ does not change when variables are added to the model.

4. The variant analysis highlights, with a $5 \%$ error probability, that the model significantly explains the variation of the dependent variable in both cases. In addition, the value for $\mathrm{F}$ change demonstrate that the variation explained by both models is significantly higher than the residual one, so the models created are effective in prediction.

- The regression equations are:

$$
\begin{gathered}
\text { air permeability }(100 \mathrm{~Pa})= \\
=34637,56-29.14^{*} \text { warpdensity }- \\
-53.21^{*} \text { weftdensity }+4.92^{*} \text { warptwist }- \\
-3.36{ }^{*} \text { wefttwist } \\
\text { air permeability }(200 \mathrm{~Pa})= \\
=61776.42-56.09{ }^{*} \text { warpdensity - } \\
-83.90 * \text { weftdensity+ } 3.39 * \text { warptwist - } \\
-3.22 * \text { wefttwist }
\end{gathered}
$$

Open problem: The prediction of the maximum warp and weft breaking force, the slippage resistance of the yarns in systems, the warp and warp tearing forces, in order to eliminate the costs with the raw materials needed for the experimental or functional models of woven structures meant for the construction of the aerodynamic stabilization-deceleration systems.

\section{CONCLUSIONS}

The paper presents the values of the canopy characteristics of a stabilization-deceleration system, resulted from tests performed in static conditions and in the subsonic aerodynamic tunnel.

The data obtained allowed the prediction of the technical-tactical performances of the stabilization-deceleration system.

\begin{tabular}{|c|c|c|c|c|c|c|c|c|c|}
\hline \multicolumn{10}{|c|}{ MODEL SUMMARY } \\
\hline \multirow[b]{2}{*}{ Model } & \multirow[b]{2}{*}{$\mathbf{R}$} & \multirow[b]{2}{*}{ R Square } & \multirow{2}{*}{$\begin{array}{l}\text { Adjusted } \\
\text { R Square }\end{array}$} & \multirow{2}{*}{$\begin{array}{l}\text { Std. Error of } \\
\text { the Estimate }\end{array}$} & \multicolumn{5}{|c|}{ Change statistics } \\
\hline & & & & & $\begin{array}{l}\text { R Square } \\
\text { change }\end{array}$ & F change & df1 & df2 & $\begin{array}{l}\text { Sig. F } \\
\text { change }\end{array}$ \\
\hline $100 \mathrm{~Pa}$ & $.971(a)$ & .942 & .936 & 159.3821 & .942 & 142.779 & 4 & 35 & .000 \\
\hline $200 \mathrm{~Pa}$ & $.978(a)$ & .956 & .951 & 214.06561 & .956 & 191.054 & 4 & 35 & .000 \\
\hline
\end{tabular}

\section{ACKNOWLEDGEMENT}

This work was carried out in the NUCLEUS Program implemented with the support of Ministry of Research and Inovation, project no. PN 163403 03, "Structura cu permeabilitate controlabila pentru stabilizatoare-deceleratoare aerodinamice verticale".

(a) Predictors: (Constant), weft and warp yarn twist, weft and warp density 


\section{BIBLIOGRAPHY}

[1] Mihai, C., Doctoral thesis, Contributii teoretice si practice la proiectarea si realizarea unor articole tehnice tesute pentru aviatie", 2004.

[2] Brown, W.D. Parachute, vol. I, II London, 1949.

[3] Knacke, T.W. Parachute Recovery Systems, Para Publishing, Santa Barbara, California, 1992.

[4] Salistean, A., Niculescu, C., Nite, C., Popescu, G., Olaru, S. Ansamblul ham/container pentru parasute sport - Un nou concept, In: Industria Textila, vol. 69, no. 3/2018, pp. 257-260.

[5] Salistean, A., Farama, D., Ciocoiu, M., Nite, C. Optimizari ale proiectarii parasutei de tip ram-container, In: IndustriaTextila, vol. 69, no. 6/2017, pp. 470-473.

\section{Authors: \\ CARMEN MIHAI ${ }^{1}$ \\ ALEXANDRA ENE 1 \\ CRISTIAN JIPA ${ }^{1}$ \\ CARMEN DENIS GHIMUS ${ }^{2}$ \\ OVIDIU DAN ZAMFIRACHE ${ }^{3}$ \\ CONSTANTIN NITE ${ }^{3}$}

${ }^{1}$ The National Research and Development Institute for Textiles and Leather

16, Lucreţiu Patraşcanu str., 030508, Bucharest

${ }^{2}$ City University of London, Department of Mathematics, London

${ }^{3}$ SC Condor SA Bucharest

Corresponding author:

CARMEN MIHAI

e-mail: carmen.mihai@certex.ro

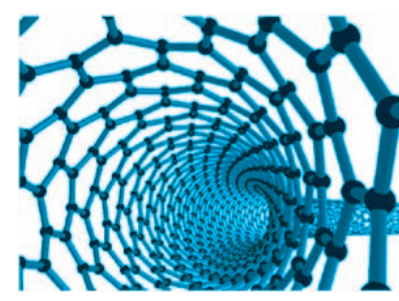

